\title{
XXXVII. Memoir on the anatomy of vegetables. Read before the Physical Class of the Institute
}

\section{Mirbel}

To cite this article: C. Mirbel (1802) XXXVII. Memoir on the anatomy of vegetables. Read before the Physical Class of the Institute, Philosophical Magazine Series 1, 13:51, 225-231, DOI: $10.1080 / 14786440208676118$

To link to this article: http://dx.doi.org/10.1080/14786440208676118

曲 Published online: 18 May 2009.

Submit your article to this journal $\sqsubset \pi$

Џ Article views: 2

Q View related articles 


\section{$\left[\begin{array}{ll}225 & 1\end{array}\right.$}

XXXVII. Memoir on the Anatomy of Vegetables. Read before the Pbyjical Clafs of the Injtitute by C. Miriec.

[Concluded from p. 179.]

\section{Chap. VII. \\ Of the Pores.}

T

HE pores are fmall apertures formed in the membranes; they favour evaporation, abforption, and the motion of the fluids. There are three kinds of them.

Ift, Tbe infenfible pores. - Thefe are apertures which cannot be perceived by the eye even when affifted by the moft powerful microfcopes. Effects, however, do not permit us to doubt of their exiftence. Every vegetable tiflue is full of them, as is proved by infenfible tranfpiration. What fhows at the fame time their extreme finenefs is the phænomenon exhibited by an apple, or any other pulpy fruit, when placed below the receiver of an air-pump : the highly dilated air efcapes only by burfting the $\mathrm{kin}$.

2d, Tbe elongated pores. -Thefe have been obferved by feveral naturalifts, and particularly Decandolle, who gave them the name of cortical pores. I fhall endeavour to complete his defeription, by uniting under the fame point of view his obfervations and thofe which I have fince made myfelf. For a knowledge of the principal facts I am indebted to his refearches; but, as he confictered this fubject rather in a phyfical than an anatomical light, his labour does not fuperfede the neceffity of publifhing mine.

The elongated pores exift only in the epidermis of the herbaceous parts expofed to the air and the light. If the exterior membrane of the vegetable be fkilfully removed, and if you then examine it with a microfcope, you will fee the interior fides of the epidermis ftill adhering, and which form as it were a hexagonal net-work; but here and there inftead of a hexagon you will obferve an ellipfe, and the part of the epidermis circumfcribed by that elliptical area is cleft in a longitudinal direction : the aperture is fometimes free, and fometimes obftructed : the latter cafe, in my opinion, arifes from the lips of the pore, longer than is neceffary to thut the aperture, being applied one to the other, and intercepting the light. The elongated pores are found commonly in the ftems, the branches, the leaves, the bracteæ, and even the herbaceous pericarpia. In herbaceous plants the two furfaces of the leaves are covered with pores; in the fat plants they are lefs numerous than in the other vegetables. In trees and fhrubs the inferior furface only is in general pierced with thefe pores. The ftems when 
they become ligneous are deftitute of them. Thefe pores ferve for the fenfible and infenfible tranfpiration and for the $a b$ forption of the fluids. They each correfpond to a fmall cell, which, according as the air is moifter than the cellular tiffue, or the cellular tiffue than the air, abforbs the fluids difperfed throughout the atmofphere, or throws off thofe which the vegetable contains. When the parts become ftiff, and the liquors contained in the vegetable have no longer the fame fluidity, thefe cells become filled with thick gum and refin; which not being able to efcape through the pores, nor to return into general circulation, become entirely hard; and are at length thrown out, when the ftate of the vegetable, by not permitting the epidermis to dilate itfelf further, forces it to burft.

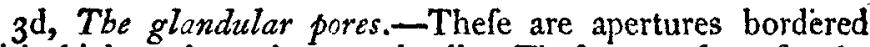
with thick opake and unequal rolls. Thefe pores ferve for the movement and communication of the fluids in the interior of the vegetable. They are obferved fometimes indeed in the epidermis, but this cafe is exceedingly rare. There are two kinds of glandular pores ${ }_{2}$ the fmall and the large. The former are exceffively fmall. To the moft powerful microfcopes they appear only like the fmall holes made in a theet of paper with the point of a needle: fometimes they are fcattered, and few in number; at other times they are very numerous, and difpofed in regular feries, always according to the breadth, and never according to the length of the tiffue. The large glandular pores are only a modification of them: one might even fuppofe that the union of the fmall pores of one feries produces the large ones, the direction of which is the fame as that of the feries. The reader muft here call to mind what I have already faid of the porous tubes, the falfe trachex, and even the tracheæ. There are fome very ftriking relations between thefe different tubes, and the plan of nature is not equivocal.

\section{Chap. VIII. \\ Of the Epidermis.}

This name is given to the exterior membrane formed by fides of the outer cells; or rather the epidermis is only the term of the cellular tiffue itfelf.

To relate every thing that authors have faid on this membrane, would fill a volume. No part in the organization of plants has given rife to more refearches, nor perhaps has led into more errors. The firft fault is, to have compared it without reftriction to the epidermis of animals. When this idea was once adopted, every thing elfe was confidered as analogous. The epidermis, faid fome writers, exifts in all or- 
ganifed beings; it covers the nafcent embryo, and the individual which has arrived at the ltate of decrepitude; it follows all the finuofities of bodies, penetrates into their cavities, and protects the moft delicate parts: thus in animals, after enveloping all the external parts, comprehending even the globe of the eye, it is feen falling back on the lips, penetrating into the inteftinal canal, into the noftrils, and the auditory paffage; and in plants, it covers the ttems, branches, leaves, flowers and fruits. The epidermis (add they) is not fimilar in every part of the fame being : fometimes it is exceedingly fine, and fometimes it affumes more confiftence; but in all cafes it is colourlefs and tranfparent. If it appears white on the trunk of the birch-tree, and brown on the young branches, afh-gray on the plum tree, red and argenteous on the cherry-tree, green on the young fhoots of the almond-tree, and ath-coloured on the old ones; this difference depends merely on the colour of the fubltances it covers, in the fame manner as the white, black, and copper colour of the white, negro or caffre depend on the colour of the mucous body. By following this comparifon, a new point of fimilitude is thought to be obferved in the dilatability of the epidermis of animals and plants : it yields to all development, and extends in proportion as the being grows : it embraces only a fmall furface in the foetus of the animal, but it dilates infenfibly and covers a much greater furface when the animal attains to its utmoft growth. It is thus that the epidermis which covers the feeds of plants dilates and yields to the increale of the fruit, and that the epidermis which covers the embryo yields alfo to the increafe of trees. The extenfion of this nembrane will be found to be prodigious, when we confider what the gourd was before its flower withered, and what the oak was when concealed in the acom. But, as there are certain animals the old epidermis of which detaches itfelf, and at the end of a certain time gives place to another; in the fame manner there are certain vegetables which throw off their epidermis in order to affume a new one. It is obferved that the epidermis of the trunk and branches of the plane-tree detaches itfelf in fcrolls like that of oviparous quadrupeds.

Thefe comparifons, no doubt ingenious, are far from being exact in every point. It may even be faid that they are founded on imperfect obfervations. To be convinced of this, it will be fufficient to reflect on the definition we have given of the epidermis of vegetables. This membrane is nothing but the exterior union of the cells of the circumference, and differs from the membranes which form the other fides only by the changes occafioned by its pofition. If it is lefs trantVoL. XIII. No. 51 .

parent, 
parent, drier and firmer, it is becaufe it is continually expofed to the influence of the light and the air, and to the contaet of all thofe bodies which float in the atmofphere: but it is not in reality a diftinct part; and it may be faid, ftrictly fpeaking, that vegetables have no organ analogous to the epidermis of animals. When vegetables grow large, the exterior membrane feems to dilate; but if this membrane becomes extended, it is becaule the number of the cells is multiplied at the circumference as at the exterior, and that confequently the fides which compofe it are multiplied in proportion, and increafe its capacity.

One objection remains to be combated. It may here be faid, Why is it fo eafy in the fpring time to detach the epidermis from the young branches, if it does not really form a diftinet organ? This may be explained in the following manner:-All caufes which have an external action on the vegetable alter its furface, and detach from it the interior parts: but this feparation becomes more apparent when the vegetation is more vigorons, and when the fluids moiften the cellular tiffue, and fill the tubes; for, as the diforganized furface cannot then develop itfelf with the reft, it ceafes to adhere, and often conses off in fragments, or is infenfibly deftroyed. This is exactly' what takes place in the fpring.

In a word, this exterior ttratum, which fo many circum. ftances tend to deftroy, and which almoft always exhibits traces of its diforganization, is not compofed of the laft membrane only: the interior part of the cellular tiffue is found in it, as is evident in the plane tree, and ftill more in the green oak, which produces cork. What has been here faid is applicable only to the ftems and branches, which do not die in the courfe of the year; for in herbs, and the annual parts of lignenus plants, fuch as the leaves, flowers, bracteæ, \&c. the furface does nut detach itfelf from the reft of the tiffue.

But the epidermis of vegetables has no refemblance to that of animals; and, though it is certainly formed by the exterior part of the cellular tiffue, it is no lefs true that its nature is modified by fecondary caufes, and that it in fact becomes an "organ, the functions of which are very diftinet, and highly important. In the infancy of the vegetable, when all the parts are foft and mucilaginous, it oppofes at the fame time the difunion of the nafcent organs, and the too ftrong action of the fluids. At a more advanced age, when the juices are lefs abundant, it prevents their too fpeedy evaporation, and maintains a juft equilibrium between the folids and the fluids. At all timcs it fecures the vegetable 
from the deleterious influence of meteors, and Melters it from exceffive heat, cold, moifture, and drought. In a word, it protects it againft all external caufes which might hurt it. Befides this, it ferves for fenfible and infenfible tranfpiration, and the abforption of gas, and of thofe fluids difperfed throughout the atmofphere. For this reafon it is often pierced with very vifible pores: I fay often, becaufe it is not indeed a general law; and the epidermis of pulpy fruits, for example, has no apparent pores. I muft add, alfo, that thefe fruits tranfpire very little, as Dr. Hales has thown in his Vegetable Statics.

\section{Chapter IX.}

On the Organizing Subfance, or Cambium of Dubamel. Hypotbejis on the Formation and Development of the Cellular Tiffue and the Tubular Tiffue.

All the parts of the vegetable have, at firft, been mucilaginous and fluid; and it is only in the fucceffion of time that the tiffie becomes firm and folid. This ftate of feeblenefs is vifible in the feed. The embryo at firft is but a drop of mucilage, in which the moft powerful microfcopes difcover no organ. This fubftance has a vitreons appearance. It is fpeedily dricd and deftroyed by the contact of the air. Properly fpeaking, it is not a fluid; it is an organized fubftance, fimilar to the white of an egro. The organizing fubttance is formed during the whole time of the increafe, and it depofits itfelf in that part of the tiffue where the vegetable ought to acquire the greateft vigour. In the monocotyledons it is placed around each ligneous filament; in dicotyledons it is at the lurface of the fuft part of the wood and the medullary canal. Every day, therefore, the ligneous filaments of the cotyledons are feen to affune more volume, and the concentric ftrata of the dicotyledons to be multiplied, and their pith to be converted into wood. The organizing fubftance is the more abundant, and is renewed with more facility as the individual is younger and founder; as it is in a more favourable fituation, and as the feafon is better fitted for vegetation. This fubftance infenfibly affumes determinate forms, whether the fluids develop in it, by their impulie, the cells and the tubes, or whether an unknown power acts in it alone, and determines thefe developments ; or whether, as is probable, thefe two caufes, united and combined, act in concert to change into membranous tiffue the organizing fub. ftance, it is certain that the vegetable acquires a more confiderable volume, and that it daily lengthens, and becomes 
thicker. To explain the two phænomena of lengthening and becoming thicker, the action of which is fimultaneous, we muft acknowledge that the expanfive force acting in the membranous tiffue newly created is modified by the nature of the tiffue itfelf. It is compofed, as we have already feen, of two organic elements, one of which is cellular tiffue, formed of the cells, whofe diameter is nearly equal in every direction; the other is the tubular tiffue, formed of the fmall and large tubes contiguous to each other. Let us fuppofe, for a moment, that the fluids imbibed by the vegetable are the capfe of this diffinilarity in the tiffue. We may do fo the more, as this fyftem is not void of probability. By way of example, let us employ the embryo: let us take the feed before fecundation: it is attached to the mother plant by the umbilical cord, the organization of which no doubt varies according to the fpecies. By the help of the veffels which unite this organ to the feed, the fluids penetrate into the organizing fubftance; and their impulle being determined by the canals which afford them a paffage, they then trace out the route which the fluids will. afterwards purfue, and determine the order of the future developments. Being vigorouny puthed in different points, which vary according to the fpecies, they open the longitudinal tubes, and then filter flowly hrough their fides, depofit themfelves in the organizing fubftance, and favour the derelopment of the cells. In the firft cafe, the fluids are pufled by the force which gives motion to the fap; in the fecond cafe, they iffue forth and penetrate the organizing fubftance only, becaufe they tend to affume an equilibrium. Thefe two forces, balanced by each other, produce a multitude of intermediate thades between the longitudinal tubes and the perfect cellular tiffue. But this theory is fill far from explaining the phrnonena of vegetable nrganization. There doubtless exift a thoufand other phyfical caufes, the influence of which cannot be calculated; and above all thefe caufes ought to be placed the organizing power, the principle of which is totally unknown to us.

However, the cells and tubes being once formed, they increafe till the infpiffation and induration of the membranes prefent an obftacle to their development. During the growth of the membranous tiffue, the fluids carried into the tubes, by feveral forces combined, determine the direction of the elongation by the imprilfe which they give to the organic moleculæ. But the cells fuffer themfelves to be penetrated by the fluids only in a now manner; and, being fubjected to no force which determines their development in one direction rather than in another, they grow and dilate themfelves 
felves in every direction. It would thence follow, if the cells grew equal in number to the tubes, that the cells ought to ferve more for extending the thicknefs than the length of the vegetable, and that the inverfe would be the cafe with the tubes; but when the latter are greatly multiplied, their number compenfates for the fmall thicknefs which each has, and they then contribute no lefs than the cells to the fenfible thickening of the vegetable. Nay more, the mals of the tubes is continually increafed in trees, while the cells are not multiplied in the fame proportion. In a word, feveral other caufes, which I thall explain hereafter, contribute to diforganize them, and even to transform them into tubes, fo that at the end of a certain time the mafs of the latter is far fuperior to that of the cells.

XXXVIII. Experiments on Electricity excited by Evaporation. By a Correspondent.
sin,
To Mr. Tilloch.

1

TAKE the liberty of communicating to you the following experiments on obtaining electricity by evaporation : and if you think them worthy of a place in your Philofophical Magazine, by inferting them therein you will very much oblige

June th, $^{\mathrm{r} 802 .}$ Your humble fervant,

\section{W. W.}

THE apparatus I ufed for this purpofe confifted of a gold leaf electrometer (hung in a phial, which had had the bottom cut off, that a condueting communication might be made between two flips of tinfoil, which were ftuck on the infide of the phial, and the earth,) and a tin dith made in the form of the fultum of a cone. The top diameter of it is about 2 inches; the bottom diameter is about $I^{1}$ inch, and its depth is about: inch. This difh, about half full of water, is placed on the electrometer, and the red-hot fubftances dropped into it from a pair of tongs, at 3 or 4 inches above it. (See Fig. 2. Pl. V.) In relating the experiments I thall put $\mathrm{P}$. and $\mathrm{N}$. to denote the two Atates, commonly denominated pofitive and negaive.

I. Cinder of pit-coal abont the fize of a walnut, dropped into the water, made the electrometer diverge N. This was repeated five times with the fame refult. Sometimes the gold leaf would beat againft the fide of the bottle four or five 